lakes (Fig. 2B). Fossils of Chironomini, a group with many species whose larvae live in and burrow into the sediments, tend to have lower $\delta^{13} \mathrm{C}$ than other groups (e.g., Tanytarsini, Orthocladiinae), suggesting that methanotrophic bacteria play a more important role in their diet than in the diets of other chironomids. This finding, together with the observed low $\delta^{13} \mathrm{C}$ in tissue and fossils of other aquatic invertebrates, such as cladocerans (water fleas) (Kankaala et al., 2006; Fig. 2B), suggests that carbon derived from methanotrophic bacteria can be consumed by a range of invertebrate groups where methanotrophic bacteria are an available food source in lakes. Hence, $\delta^{13} \mathrm{C}$ of fossil aquatic invertebrates can provide insights into the past availability and importance of methanotrophic microorganisms in different parts of lake ecosystems and, indirectly, on past methane production and oxidation in lakes (van Hardenbroek et al., 2009a). Similarly, analyses of aquatic invertebrate $\delta^{15} \mathrm{~N}$, and especially the comparison of $\delta^{13} \mathrm{C}$ and $\delta^{15} \mathrm{~N}$, can provide valuable information on changes in the past trophic position of invertebrate groups within lacustrine food webs.

\section{Future directions}

Analytical methods available for analyzing stable isotopes in organic remains of aquatic invertebrates have progressed to the stage where fossils of individual taxa (e.g., species, genera, or subfamilies) can be measured. This allows inferences to be made in respect to past environmental conditions in different parts of lake ecosystems and about past food sources and the past trophic position of aquatic invertebrate taxa. However, the structural integrity of organic microfossils does not guarantee that the chemical composition of these structures has not been altered by degradational or diagenetic processes. Efforts are necessary to assess how degradation potentially affects the stable isotopic composition of these fossils. Moreover, fractionation processes associated with intake of diet and water by aquatic invertebrates need further detailed investigations. In particular, the complex biochemical reactions associated with the formation of the invertebrate exoskeleton could influence the stable isotopic composition of fossilizing structures. Laboratory experiments studying stable isotopes in aquatic invertebrates and their fossilizing structures in respect to the isotopic composition of their food (e.g., van Hardenbroek et al., 2009a) and of lake water (e.g., Wang et al., 2009) are therefore needed to better constrain the interpretation of these stable isotope records from sediments. To develop this approach further, datasets that document the stable isotope composition of aquatic invertebrates in lakes, covering a wide range of environmental conditions, will be necessary. It can be expected that such detailed calibration datasets will allow quantitative paleoenvironmental reconstructions based on stable isotopes of fossil invertebrate remains, and significantly expand both the applicability and reliability of this new approach.

\section{References}

van Hardenbroek, M., Heiri, 0., Grey, J., Bodelier, P.L.E., Verbruggen, F. and Lotter, A.F., 2009a: Fossil chironomid $\delta^{13} \mathrm{C}$ as a proxy for past methanogenic contribution to benthic food webs in lakes? Journal of Paleolimnology, D0I 10.1007/s10933-009-9328-5.

Wang, Y., Francis, D.R., O'Brien, D.M. and Wooller, M.J., 2008: A protocol for preparing subfossil chironomid head capsules (Diptera: (hironomidae) for stable isotope analysis in paleoclimate reconstruction and considerations of contamination sources, Journal of Paleolimnology, 40: 771-781.

Wang, Y.V., O'Brien, D.M., Jenson, J., Francis, D. and Wooller, M.J., 2009 The influence of diet and water on the stable oxygen and hydrogen isotope composition of Chironomidae (Diptera) with paleoecological implications, Oecologia, DOI 10.1007/s00442009-1303-3.

Wooller, M., Wang, Y. and Axford, Y., 2008: A multiple stable isotope record of Late Quaternary limnological changes and chironomid paleoecology from northeastern Iceland, Journal of Paleolimnology, 40: 63-77.

Wooller, M.J., Francis, D., Fogel, M.L., Miller, U., Walker, I.R. and Wolfe, A.P. 2004: Quantitative paleotemperature estimates from $\delta^{18} 0$ of chironomid head capsules preserved in arctic lake sediments, Journal of Paleolimnology, 31: 267-274.

For full references please consult:

www.pages-igbp.org/products/newsletters/ref2009_3.html

\title{
Microbial membrane lipids in lake sediments as a paleothermometer
}

\author{
Johan W.H. Weijers ${ }^{1}$, C.I. Blaga ${ }^{1}$, J.P. Werne ${ }^{2}$ AND J.S. Sinninghe Damsté ${ }^{1,3}$ \\ ${ }^{1}$ Faculty of Geosciences, Utrecht University, The Netherlands; j.weijers@geo.uu.nl \\ ${ }^{2}$ Large Lakes Observatory and Department of Chemistry and Biochemistry, University of Minnesota Duluth, USA; ${ }^{3}$ Department of Marine Or- \\ ganic Biogeochemistry, Royal Netherlands Institute for Sea Research,'t Horntje (Texel), The Netherlands
}

\section{New organic geochemical technique has potential for reconstructing absolute lake surface and lake catchment temperatures in paleolimnological studies}

Lake sediments are an essential source of data on past climate change on the continents. Paleolimnological techniques designed to reconstruct continental temperature changes have primarily focused on carbonate sources and oxygen isotopes in biogenic silica (e.g., von Grafenstein et al., 1994; Rietti-Shanti et al., 1998). Transfer functions aimed at absolute temperature reconstructions from biological records are promising for pollen and chironomids (e.g., Walker et al., 1991; Lotter et al., 1997). Obviously, not all lake records contain carbonates, chironomids or pollen. Clearly, it is desirable to have different tools at hand for temperature reconstructions as the best reconstructions are to be obtained by means of multi-proxy approaches. An opportunity to expand this proxy "toolbox" comes from microbial cell membrane lipids, which might be used to reconstruct lake surface water temperatures and catchment air temperatures.

\section{Lake surface paleothermometer}

Because of their wide application in marine environments, considerable interest has developed in recent years for the application of isoprenoid Glycerol Dialkyl Glycerol Tetraether (GDGT) membrane lipids as temperature indicators of lakes. In the marine environment, these lipids are synthesized by pelagic non-thermophilic Crenarchaeota and the degree of inter- nal cyclization of GDGTs, expressed in the TEX $_{86}$ (TetraEther indeX of molecules containing 86 carbon atoms) shows a strong relation with sea surface temperature (Schouten et al., 2002; Kim et al., 2008). This proxy has since found many applications in marine sediment records (e.g., Sluijs et al., 2006). Further, preliminary analyses of surface sediments from four globally distributed large lakes by Powers et al. (2004) demonstrated the presence of crenarchaeotal GDGTs, and thus showed potential for application of TEX $_{86}$ in lacustrine systems. The initial calibration curve of $\mathrm{TEX}_{86}$ in lakes, based on comparison of the GDGT composition of lake surface sediments with published mean annual 


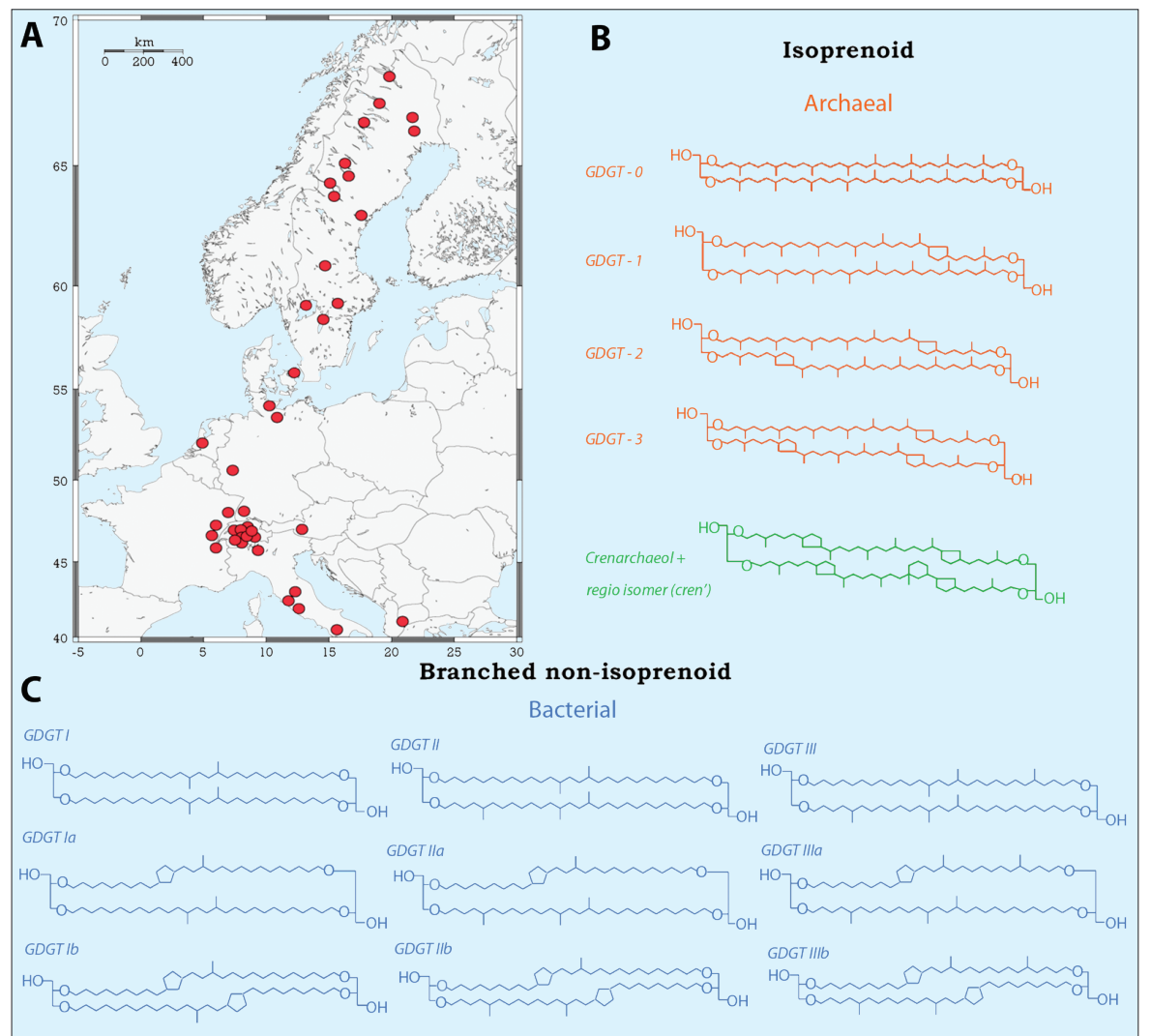

Figure 1: A) Location map of European lakes (left) investigated for the presence of different types of Glycerol Dialkyl Glycerol Tetraether (GDGT) membrane lipids (right). Redrawn from Blaga et al. (2009). B) GDGTs 1, 2, 3 and the regioisomer of crenarchaeol (cren'; a different stereochemical structure) are used in the TEX ${ }_{86}$ lake surface temperature proxy. Both crenarchaeol and its regio-isomer are uniquely synthesized by Crenarchaeota, whereas the other GDGTs (0-3) could also be produced by other Archaea, e.9., methane producing Euryarchaeota. C) Branched GDGTs (IIII) are synthesized by as yet unknown bacteria predominantly occurring in soils and peat. The abundance of these branched GDGTs relative to Crenarchaeol (the Branched vs. Isoprenoid Tetraether (BIT) index) is a measure of the relative input of soil organic matter to aquatic sediments. The degree of branching (GDGTS I-III) and the degree of cyclization (GDGTs a-b) of these GDGTs are reflecting both annual mean air temperature and soil pH.

lake surface water temperatures (LSTs), was almost identical to the one obtained by Schouten et al. (2002) for the marine system. Using this calibration, down-core applications of $\mathrm{TEX}_{86}$ in lakes have been described for Lake Malawi and Lake Tanganyika (Powers et al., 2005; Tierney et al., 2008). In order to extend the calibration curve for TEX ${ }_{86^{\prime}}$ Blaga et al. (2009) analyzed surface sediments from 47 lakes distributed over a temperature gradient in Europe (Fig. 1). This study indicated that the relationship between TEX ${ }_{86}$ and LST in lacustrine environments may be hampered by several factors.

\section{Sources of GDGTs in lakes}

Of crucial importance for the GDGTs found in lake sediments is that their origin is not necessarily restricted to a single group of Archaea. Next to the aquatic Crenarchaeota, which produce the TEX ${ }_{86}$ signal, soil Crenarchaeota and Euryarchaeota (mainly methanogenic Archaea) also synthesize some of the lipids used in TEX ${ }_{86}$ (Wakeham et al., 2003; Weijers et al., 2006). The ternary diagram in Figure 2 shows the distribution of the major GDGTs in sediments from the European lakes, as well as in soils and marine sediments. Crenarchaeol is uniquely synthesized by Crenarchaeota, Figure 2 defing in the red boxed ship between TEX ${ }_{86}$ and LST be established for 8 lakes. Based on these lakes, the relation suggests that the values of the proxy might reflect winter temperatures rather than mean annual tempera- tures, but molecular ecological studies of lakes are required to confirm this.

\section{Sediment traps}

Support for the potential, and a clarification of the constraints of TEX ${ }_{86}$ applications in lakes is provided by a recent study involving a sediment trap in African Lake Challa (Sinninghe Damsté et al., 2009). $\mathrm{TEX}_{86}$ values derived from sinking particulate OM collected at $35 \mathrm{~m}$ depth in the water column correctly reflect in situ ambient water temperatures of the oxygenated part of the water column. TEX ${ }_{86}$ values of contemporary lake surface sediments, however, were obscured by a contribution of similar GDGTs most likely derived from deep-water anaerobic Archaea, and therefore do not reflect LST. These and previous results illustrate that the full complement of GDGTs necessary to calculate TEX86 values is present in many lakes, and thus show promise for the reconstruction of LSTs. However, these studies also demonstrate that the source of GDGTs in lake sediments should be well constrained before applying the $\mathrm{TEX}_{86}$ paleothermometer.

\section{Lake catchment paleothermometer}

Where a large soil OM flux complicates use of TEX $_{86^{\prime}}$ it could provide an opportunity to apply another recently developed temperature proxy based on the branched GDGT lipids derived from soils. These GDGTs, synthesized by as yet unknown bacteria, differ in the amount of rings and branches in their carbon structure (Fig. 1). Comparison of branched GDGT distributions in $>100$ worldwide distributed soils with environmental parameters showed that their composition is determined by both soil $\mathrm{pH}$ and annual mean air temperature (MAT). This relation led to the development of the MBT-CBT proxy (Methylation index and Cylcization ratio of Branched Tetraethers, respectively) for MAT, which has been successfully applied in marine sediment archives (Weijers et al., 2007a; b; c). Therefore, this proxy bears potential for application in lake sedimentary archives to reconstruct MATs of the lake catchment area. Preliminary analysis of some lake sediments showed promising results, e.g., Lago di Vico (Italy) and a small lake from Brazil, where reconstructed MATs are close to measured MATs from nearby weather stations (Blaga et al., unpublished). Also in a long sediment core from Valles Grande Caldera in New Mexico (USA), the MBTCBT proxy captures glacial-interglacial transitions and matches the pollen records from this lake (Werne et al., unpublished). In some other cases, however, re- 


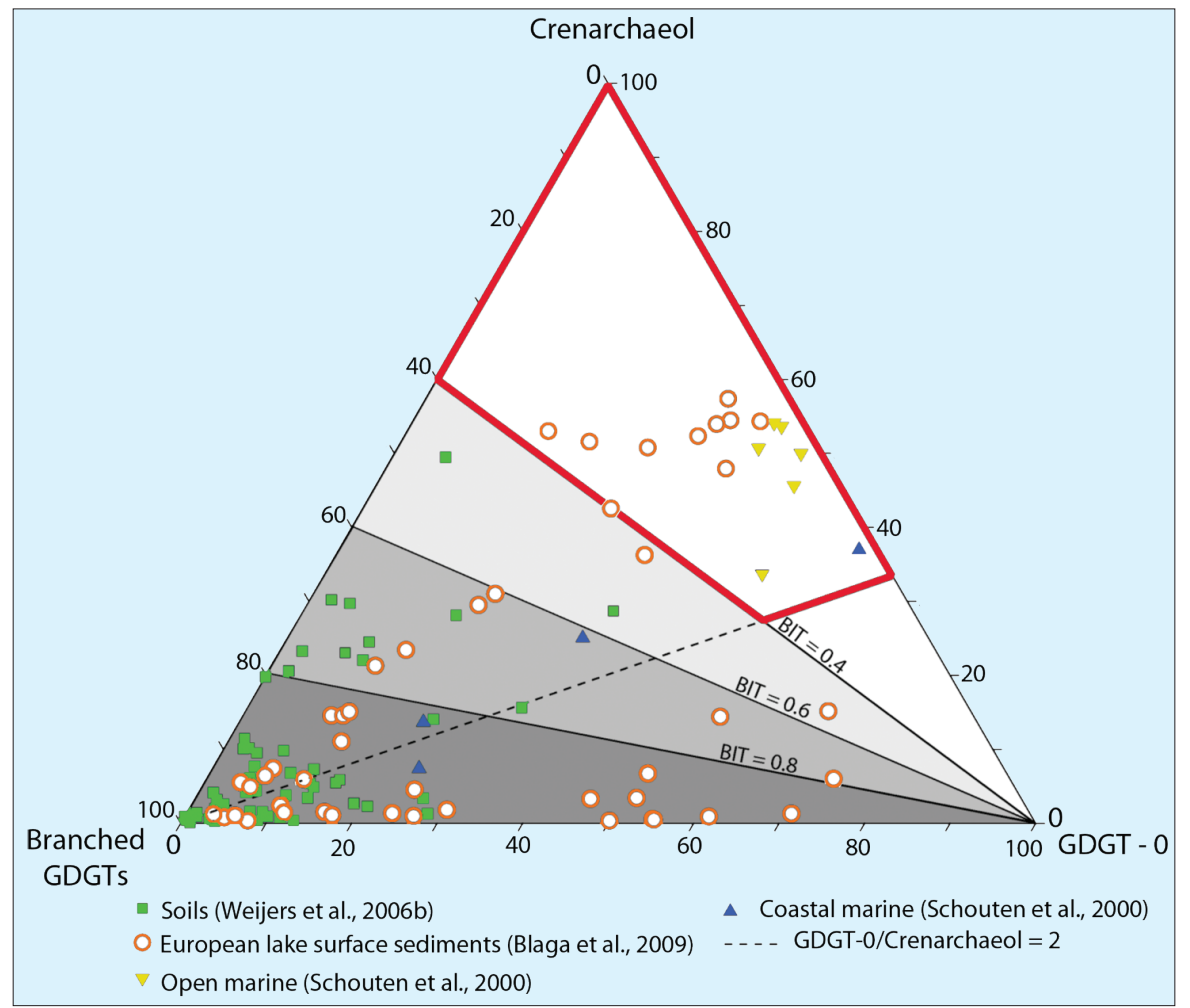

Figure 2: Ternary diagram showing the relative distribution of the three main types of GDGTs (drawn in Fig. 1) in different sedimentary environments. Lakes plotting in the red boxed area have potential for application of the TEX ${ }_{86}$ proxy. See text for further explanation. Adapted from Blaga et al. (2009).

constructed MATs from surface sediments seem to be lower than measured MATs. An explanation for this mismatch could be the production of branched GDGTs in situ in lake sediments, which are in fact aquatic soils. Recently, this possibility has indirectly been shown for sediments from a fjord (Peterse et al., 2009) and two tropical lakes (Tierney and Russel, 2009;

\section{Conclusions}

Both organic geochemical paleothermometers, TEX $_{86}$ and MBT-CBT, are promising new proxies for reconstructing LST and MAT, respectively, from the GDGT lipid distribution in lake sediments. Care should be taken, however, where these proxies are applied: TEX $_{86}$ seems mainly applicable in larger lakes that receive little soil OM input and do not contain large communities of methane-producing Archaea, whereas MBT-CBT seems to be most useful in lakes that do receive a large influx of soil OM relative to in situ production of branched GDGTs in the lake sediments.

\section{References}

Blaga, C.I., Reichart, G.-J., Heiri, 0. and Sinninghe Damsté, J.S. 2009: Tetraether membrane lipid distributions in water-column particulate matter and sediments: a study of 47 European lakes along a north-south transect, Journal of Paleolimnology, 41:523-540.

Powers, L.A., Werne, J.P., Johnson, T.C., Hopmans, E.C., Sinninghe Damsté, J.S. and Schouten, S., 2004: Crenarchaeotal membrane lipids in lake sediments; a new paleotemperature proxy for continental paleoclimate reconstruction? Geology, 32: 613-616.

Schouten, S. Hopmans, E.C. Schefuss, E. and Sinninghe Damsté, J.S. 2002: Distributional variations in marine crenarchaeotal membrane lipids: a new tool for reconstructing ancient sea wate temperatures? Earth and Planetary Science Letters, 204: 265274.

Sinninghe Damsté, J.S., Ossebaar, J., Abbas, B., Schouten, S. and Verschuren, D., 2009: Fluxes and distribution of tetraether lipids in an equatorial African lake: Constraints on the application of the TEX palaeothermometer and BIT index in lacustrine settings, Geochimica et Cosmochimica Acta, 73: 4232-4249.

Weijers, JW. W. Schouten, S, van den Donker, J.C, Hopmans, EC and Sinninghe Damsté, J.S., 2007a: Environmental controls on bacterial tetraether membrane lipid distribution in soils, Geochimica et Cosmochimica Acta, 71: 703-713. in situ GDGT production might be biased towards lake bottom water temperatures.

\title{
Ancient DNA in lake sediment records
}

\author{
Marco J.L. Coolen ${ }^{1}$ and John A.E. Gibson ${ }^{2}$
}

'Department of Marine Chemistry and Geochemistry, Woods Hole Oceanographic Institution, USA; mcoolen@whoi.edu ${ }^{2}$ Marine Research Laboratories, University of Tasmania, Hobart, Australia

\section{Ancient DNA in lake sediments offers a novel window into past aquatic ecosystems and the environmental changes that triggered past species successions.}

The geological record offers our best opportunity for understanding how biological systems function over long timescales and under varying paleoenvironmental conditions. Understanding these ecosystem responses to change is critical for biologists trying to understand how organisms interact and adapt to environmental changes, and for geologists seeking to use these biology-geology relationships in order to reconstruct past climate conditions from sediment records. For example, enumeration of microscopic fossilizing protists, such as diatoms, has become a standard paleoecological approach in the fields of paleoclimatology and paleolimnology. However, the identification of morphological remains is not always straightforward, as many taxa lack diagnostic features preserved upon fossilization. Lipid-based records can be particularly valuable for species that do not leave diagnostic features in the sedimentary record. Nevertheless, the interpretation of these molecular stratigraphic records is often complicated by the limited specificity of many lipid biomarkers.

There is thus a need to find new biomarkers with greater source-specificity that can be used to complement and enhance interpretations based on existing methods. The field of molecular biology offers a most promising approach/technique that is just starting to gain wider utility: The use of ancient DNA preserved in the sedimentary record (i.e., fossil DNA or fDNA) to reconstruct past ecosystems. Fossil DNA has been successfully employed to study the succession of species as a result of environmental changes in terrestrial (e.g., Willerslev et al., 2007), marine (Boere et al., 2009; Coolen et al., 2007; 2009; Coolen and Overmann, 2007; Manske et al., 2008), and lacustrine settings (Bissett et al., 2005; Coolen et al., 2004; 2008; Coolen and Overmann, 1998; D'Andrea et al., 2006; Epp et al., 2009). A major advantage of this molecular paleoecological approach is that ancient species can be studied, including those with- 


\section{Full Reference List:}

Blaga, C.I., Reichart, G.-J., Heiri, O. and Sinninghe Damsté, J.S. 2009: Tetraether membrane lipid distributions in water-column particulate matter and sediments: a study of 47 European lakes along a north-south transect, Journal of Paleolimnology, 41: 523-540.

Kim J-H., Schouten S., Hopmans E.C., Donner B. and Sinninghe Damsté J.S., 2008: Global sediment core-top calibration of the TEX 86 paleothermometer in the ocean, Geochimica et Cosmochimica Acta, 72: 11541173.

Lotter, A.F., Birks, H.J.B., Hofmann, W. and Marchetto, A., 1997: Modern diatom, cladocera, chironomid and chrysophyte cyst assemblages as quantitative indicators for the reconstruction of past environmental conditions in the Alps. I. Climate, Journal of Paleolimnology, 18: 395-420.

Peterse, F., Kim, J-H., Schouten, S., Klitgaard-Kristensen, D., Koç, N. and Sinninghe Damsté, J.S., 2009: Constraints on the application of the MBT/CBT paleothermometer at high latitude environments (Svalbard, Norway), Organic Geochemistry, 40: 692-699.

Powers, L.A., Werne, J.P., Johnson, T.C., Hopmans, E.C., Sinninghe Damsté, J.S. and Schouten, S., 2004: Crenarchaeotal membrane lipids in lake sediments; a new paleotemperature proxy for continental paleoclimate reconstruction? Geology, 32: 613-616.

Powers, L.A., Johnson, T.C., Werne, J.P., Castañeda, I.S., Hopmans, E.C., Sinninghe Damsté, J.S. and Schouten, S., 2005: Large temperature variability in the southern African tropics since the Last Glacial Maximum, Geophysical Research Letters, 32: L08706, doi:10.1029/2004GL022014.

Rietti-Shanti, M., Shemesh, A. and Karlen, W., 1998: A 3000-year climatic record from biogenic silica oxygen isotopes in an equatorial high altitude lake, Science, 281: 980-982.

Schouten, S., Hopmans, E.C., Schefuss, E. and Sinninghe Damsté, J.S., 2002: Distributional variations in marine crenarchaeotal membrane lipids: a new tool for reconstructing ancient sea water temperatures? Earth and Planetary Science Letters, 204: 265-274.

Sinninghe Damsté, J.S., Ossebaar, J., Abbas, B., Schouten, S. and Verschuren, D., 2009: Fluxes and distribution of tetraether lipids in an equatorial African lake: Constraints on the application of the TEX 86 palaeothermometer and BIT index in lacustrine settings, Geochimica et Cosmochimica Acta, 73: 42324249.

Sluijs, A. and Schouten, S. et al., 2006: Subtropical Arctic Ocean temperatures during the Palaeocene/Eocene thermal maximum, Nature, 441: 610-613.

Tierney, J.E., Russel, J.M., Huang, Y., Sinninghe Damsté, J.S., Hopmans, E.C. and Cohen, A.S., 2008: Northern Hemisphere controls on tropical Southeast African climate during the past 60,000 years, Science, $\mathbf{3 2 2}$ : 252-255.

Tierney, J.E. and Russel, J.M., 2009: Distributions of branched GDGTs in a tropical lake system: implications for lacustrine application of the MBT/CBT paleoproxy, Organic Geochemistry, 40: 1032-1036.

von Grafenstein, U., Erlenkeuser, H., Kleinmann, J., Muller, J. and Trimborn, P., 1994: High frequency climatic oscillations during the last deglaciation as revealed by oxygen-isotope records of benthic organisms (Ammersee, southern Germany), Journal of Paleolimnology, 11: 349-357.

Wakeham, S.G., Lewis, C.M., Hopmans, E.C., Schouten, S. and Sinninghe Damsté, J.S., 2003: Archaea mediate anaerobic oxidation of methane in deep euxinic waters of the Black Sea, Geochimica et Cosmochimica Acta, 67: 1359-1374.

Walker, I.R., Smol, J.P., Engstrom, D.R. and Birks, H.J.B., 1991: An assessment of Chironomidae as quantitative indicators of past climatic change, Canadian Journal of Fisheries and Aquatic Science, 48: 975-987.

Weijers, J.W.H., Schouten, S., Spaargaren, O.C. and Sinninghe Damsté, J.S., 2006: Occurrence and distribution of tetraether membrane lipids in soils: Implications of the use of the TEX 86 proxy and the BIT index, Organic Geochemistry, 37: 1680-1693.

Weijers, J.W.H., Schouten, S., van den Donker, J.C., Hopmans, E.C. and Sinninghe Damsté, J.S., 2007a: Environmental controls on bacterial tetraether membrane lipid distribution in soils, Geochimica et Cosmochimica Acta, 71: 703-713.

Weijers, J.W.H., Schefuß, E., Schouten, S., Sinninghe Damsté, J.S., 2007b: Coupled thermal and hydrological evolution of tropical Africa over the last deglaciation, Science, 315: 1701-1704.

Weijers, J.W.H., Schouten, S., Sluijs, A., Brinkhuis, H. and Sinninghe Damsté, J.S., 2007c: Warm arctic continents during the Palaeocene-Eocene thermal maximum, Earth and Planetary Science Letters, 261: 230-238. 